African Crop Science Journal by African Crop Science Society is licensed under a Creative Commons Attribution 3.0 Uganda License. Based on a work at www.ajol.info/ and www.bioline.org.br/cs DOI: http://dx.doi.org/10.4314/acsj.v26i1.4

\title{
EVALUATION OF RICE CULTIVARS FOR RESISTANCE TO RICE YELLOW MOTTLE VIRUS
}

\section{H. KAM, M.-N. NDJIONDJOP ${ }^{1}$, N. OUEDRAOGO, M.D. LAING ${ }^{2}$ and A. GHESQUIERE ${ }^{3}$}

\author{
Environmental and Agricultural Research Institute (INERA), 01910 Bobo - Dioulasso, Burkina Faso \\ ${ }^{1}$ Africa Rice Center (AfricaRice), 01 BP 2551 Bouaké, Côte d'Ivoire \\ ${ }^{2}$ University of KwaZulu-Natal (UKZN), School of Agricultural Earth and Environmental Sciences (SAEES), \\ College of Agriculture, Engineering and Science, Pietermaritzburg, South Africa \\ ${ }^{3}$ Institute of Research and Development (IRD), Montpellier, France
} Corresponding author: kamhonore@gmail.com

(Received 30 April, 2017; accepted 8 February, 2018)

\begin{abstract}
Rice yellow mottle virus (RYMV), which is only found in Africa, threatens rice farming on the continent. A local Oryza sativa cultivar collected from Burkina Faso (named BM24), was evaluated with that of well known highly resistant and tolerant cultivars. Firstly, three RYMV isolates were used to characterise the differential interaction within the cultivars. Secondly, disease kinetics of symptom expression and virus titer on leaves at 21 days after inoculation were assessed using the BF1 isolate. Thirdly, the allelic profile of $O$. sativa varieties using SSR marker RM101 located on chromosome 12 was also assessed. IR64 showed susceptibility to all isolates; while Tog5681 was resistant to all isolates. $\mathrm{Ng} 122$ overcame the resistance of Gigante, with mild leaf symptoms at 42 dpi. Azucena and BM24 had, therefore, different resistance level regarding the three isolates $(\mathrm{Ng} 117 \mathrm{~b}, \mathrm{Ng} 122$ and $\mathrm{Ng} 144)$. When infected with the isolate, BF1, BM24 and Azucena exhibited same resistance patterns in early growth stages with delayed of symptoms appearance, but BM24 outperformed Azucena at later stages. The virus content in the two accessions, at 14 days post inoculation, was statistically different with BM24, showing less virus compared to Azucena. However, the two accessions depicted an identical allelic profile at RM101 locus.
\end{abstract}

Key Words: Azucena, Burkina Faso, local variety, Oryza sativa

\section{RÉSUMÉ}

Le virus de la panachure jaune du riz (RYMV) est endémique seulement en Afrique, et fait des ravages dans les rizières du continent. Une variété de riz local (appelée BM24), résistante au RYMV et collectée au Burkina Faso a été comparée avec des cultivars bien connus qui sont résistants ou tolérants au RYMV. Tout d'abord, trois isolats ont été utilisés pour caractériser les interactions différentielles au sein des cultivars. Ensuite, la cinétique de l'expression des symptômes de la maladie et le titre en virus sur les feuilles à 21 jours après inoculation ont été évaluée avec l'isolat BF1. Enfin, le profile allélique des variétés de Oryza sativa a été évalué au marqueur SSR RM101 situé sur le chromosome 12. La variété IR64 s'est avérée sensible à tous les isolats tandis que Tog5681 s'est montré résistant à tous les isolats. L'isolat $\mathrm{Ng} 122$ a surmonté la résistance de Gigante avec la présence de symptômes modérés à 42 jours après inoculation (JAI). Azucena et BM24 par contre ont eu différents niveaux de résistance en présence des trois isolats $(\mathrm{Ng} 117 \mathrm{~b}, \mathrm{Ng} 122$ and $\mathrm{Ng} 144)$. Lorsqu'ils sont infectés avec l'isolat BF1, BM24 et Azucena expriment le même niveau de résistance avec un retard de l'apparition des symptômes dans les premiers moments suivant l'inoculation mais au-delà de $14 \mathrm{JAI}$, les symptômes apparaissent plus 
rapidement chez Azucena comparé à BM24. A 14 JAI, le titre de virus contenu dans e cultivar Azucena est bien supérieur statistiquement à celui de BM24. Cependant, les deux cultivars ont eu un profile allélique identique au locus RM101.

Mots Clés: Azucena, Burkina Faso, variété locale, Oryza sativa

\section{INTRODUCTION}

In Africa, two rice species are cultivated, the African rice (Oryza glaberrima) and the Asian rice (Oryza sativa). These two rice species are affected by Rice yellow mottle virus (RYMV) disease, which is only found on this continent (Kouassi et al., 2005). The screening of cultivars belonging to both cultivated species, by several authors identified two major genes of resistance: $R Y M V 1$ and $R Y M V 2$, which provide high levels of resistance (Fomba 1988; Ndjiondjop et al., 1999; Rakotomalala et al., 2008; Thiémélé et al., 2010). High resistance is characterised by symptomless plants and the blockage of virus movement inside the plant (Ndjiondjop et al., 2001).

African rice bears the $R M Y V l$ gene that has 3 alleles (Rymv1-3; Rymv1-4; and Rymv15); while one allele (Rymv1-2) was found in Asian rice (Albar et al., 2006). Rymv1-2 has only been detected in Gigante and Bekarosaka, which are two cultivars of Asian rice var. indica (Ndjiondjop et al., 2001; Rakotomalala et al., 2008). RYMV2 was recently found in the African rice cultivar Tog7291 (Thiémélé et al., 2010). Moreover, some cultivars of Asian rice var. japonica showed partial resistance, associated with tolerance, which is under multi-genic control (Ghesquière et al., 1997; Albar et al., 1998; Ioannidou et al., 2000). Partial resistance is expressed only at the early stages of infection. It is characterised by delayed and reduced virus accumulation in leaves, and delayed virus invasion in bundle sheath tissues (Ioannidou et al., 2003). The tolerance in Azucena was apparent at the later stages of infection, and was characterised by reduced symptom expression, despite high virus titer (Ioannidou et al., 2000). Partial resistance was reported previously in cultivar Azucena (Albar et al., 1998; Pressoir et al., 1998; Ahmadi et al., 2001; Boisnard et al., 2007).

Preliminary research identified only a quantitative trait locus (QTL) on chromosome 12 providing host plant resistance to RMYV in the cultivar Azucena (Ghesquière et al., 1997). Later, three QTLs on chromosomes 1 , 2 and 12 respectively, were suggested to be involved in the partial resistance mechanisms of Azucena. QTL1 appears to be implicated in the resistance of virus accumulation and the expression of symptoms; while QTL2 and QTL12 were said to be involved in mechanisms contributing to the decrease in virus accumulation and symptom expressions (Albar et al., 1998).

The complementary epistasis between QTL12 and QTL7 was identified as a genetic factor controlling the virus titer and conferring resistance to Azucena (Pressoir et al., 1998; Ahmadi et al., 2001). The QTL12 close to the indica-japonica zone of differentiation is bracketed in an interval of $2.23 \mathrm{Mb}$ that includes the RM101 locus (Boisnard et al., 2007). This interval is relatively large due to lack of recombination and, therefore, makes it difficult to fine map QTL12 involved in the partial resistance of Azucena. Another $O$. sativa source of resistance to RYMV was identified in a screening of rice landraces from Burkina Faso (Kam et al., 2013).

The objective of this study was to characterise the response to RYMV infection in this local cultivar (BM24) against well known highly resistant and tolerant cultivars. 


\section{MATERIALS AND METHODS}

Virus multiplication and inoculation. Four RYMV isolates were used in this study in 2015: one from Burkina Faso (BF1) and three from Niger (Ng117b, Ng122 and Ng144). Niger's isolates were from a collection kept at the Plant Pathology Unit of Africa Rice Center. The isolates were selected due to their interaction with different resistance genes and alleles (Sow et al., 2015). BF1 is an aggressive RYMV S2 strain, previously employed in the characterisation of QTL7 and QTL12 in Azucena (Albar et al., 1998; Pressoir et al., 1998; Ahmadi et al., 2001). Isolates $\mathrm{Ng} 117$ b, $\mathrm{Ng} 122$ and $\mathrm{Ng} 144$ were multiplied on the standard susceptible cultivar, IR64, for 2 weeks. The BF1 isolate provided by the Institute of Research and Development (IRD, Montpellier, France) had already been multiplied in cultivars IR64 in 2006 and stored at $-80^{\circ} \mathrm{C}$ in liquid nitrogen. Mechanical inoculation was performed with infected leaf samples ground in phosphate buffer at $\mathrm{pH} 7.2$ (10 $\mathrm{ml} \mathrm{g}^{-1}$ of leaf sample). Carborundum (600 mesh) was added to the extracts as an abrasive agent. Mechanical inoculation was carried out by rubbing the extracted sap on the upper and lower leaf surfaces of 2 weeks old plants by finger-dipping in the inoculum.

\section{Cultivar resistance to $\mathrm{Ng117b}, \mathrm{Ng122}$ and}

Ng144 isolates. The first experimental setup was performed in a greenhouse at the Africa Rice Research Station at Cotonou, Benin. Resistance of accession BM24 was evaluated using three isolates $(\mathrm{Ng} 117 \mathrm{~b}, \mathrm{Ng} 122$ and $\mathrm{Ng} 144)$. The experiment was conducted in the presence of four cultivar checks, namely Gigante and Tog5681; which bear the Rymv12 and the Rymv $1-3$ recessive resistant alleles, respectively; the highly susceptible cultivar IR64 and the moderately resistant cultivar Azucena. The experimental design was with three replications. The main plots were the four treatments (isolates $\mathrm{Ng} 117 \mathrm{~b}, \mathrm{Ng} 122$ and $\mathrm{Ng} 144$ and a non-inoculated control) and the sub-plots were for testing accessions and check cultivars.

The plot unit was an individual plant in a plastic pot of $5 \mathrm{~L}$. The disease scores were monitored weekly from 14 days postinoculation (dpi) until 49 dpi. Plant height was measured at 49 dpi to estimate height reduction between inoculated and non-inoculated plants. The disease notation was as described in standard evaluation system for RYMV symptoms of the International Rice Research Institute (IRRI, 2002). The severity scale ranged from 1 to 9 . There were five classes of symptoms classification under the following scores: 1 (no symptom observed; i.e., highly resistant or HR), 3 (green leaves with sparse dots or streaks; i.e., moderately resistant or MR), 5 (general mottling on the leaves and 6 to $25 \%$ of reduction of plant height; i.e., moderately susceptible or MS), 7 (yellowing and stunting; i.e., susceptible or S) and 9 (for necrosis to plant death; i.e., highly susceptible or HS).

Analysis of variance (ANOVA) was performed on plant height data using GeneStat software Version 12 (Payne et al., 2009). Linear model was defined as:

$\mathrm{y}_{\mathrm{ijk}}=\mu+\mathrm{a}_{\mathrm{i}}+\mathrm{t}_{\mathrm{j}}+\mathrm{r}_{\mathrm{k}}+\mathrm{a}_{\mathrm{ij}}+\mathrm{t}_{1}+\varepsilon_{2} \ldots \ldots \ldots$

Where:

$\mathrm{y}_{\mathrm{ijk}}=$ the plant height for accession $i$ of treatment $j$ in replication $k, \mu=$ the mean effect, $\mathrm{a}_{\mathrm{i}}=$ the $\mathrm{i}^{\text {th }}$ effect of the accession $i, \mathrm{t}_{\mathrm{j}}=$ the $\mathrm{j}^{\text {th }}$ the effect of the treatment $j, \mathrm{r}_{\mathrm{k}}=$ the $\mathrm{r}^{\text {th }}$ the effect of the replication $k$, a. $t_{\mathrm{ij}}=$ the interaction between accession $i$ and treatment $j, \bullet \varepsilon_{1}$ is the main plot error term, and $\varepsilon_{2}$ the subplot error term. The Least Significance Difference (LSD) test at 5\% level was used for mean comparison.

As disease scores were measured at different times, a repeated measured model was adopted for the ANOVA and was computed using the software GeneStat version 12 (Payne et al., 2009). The model used was as follows: 
$\mathrm{y}_{\mathrm{ijkn}}=\mu+\mathrm{a}_{\mathrm{i}}+\mathrm{t}_{\mathrm{j}}+\mathrm{r}_{\mathrm{k}}+\mathrm{T}_{\mathrm{n}}+\mathrm{a} \cdot \mathrm{t}_{\mathrm{ij}}+\mathrm{a} \cdot \mathrm{T}_{\mathrm{in}}+\mathrm{t} \cdot \mathrm{T}_{\mathrm{jn}}$ + a.t. $\left.T_{\mathrm{ijn}}+\bullet \varepsilon_{1}+\varepsilon_{2}\right]$

Where:

$\mathrm{y}_{\mathrm{ijkn}}=$ the disease score for accession $i$ of treatment $j$ in replication $k$ at time $n, \mu=$ the mean effect, $a_{i}=$ the effect of the accession $i, \mathrm{t}_{\mathrm{j}}=$ the effect of the treatment $j, \mathrm{r}_{\mathrm{k}}=$ the effect of the replication $k, \mathrm{~T}_{\mathrm{n}}=$ the effect of the time $n$, a.t $_{\mathrm{ij}}=$ the effect of the interaction between accession $i$ and treatment $j$, a. $\mathrm{T}_{\text {in }}=$ the interaction between accession $i$ and time $n, \mathrm{t}_{\mathrm{j}} \mathrm{T}_{\mathrm{jn}}=$ the interaction between treatment $j$ and time $n$, a.t. $\mathrm{T}_{\mathrm{ijn}}=$ the three way interaction effect between accession $i$ with treatment $j$ and time $n, \varepsilon_{1}=$ the main plot error term, and $\varepsilon_{2}=$ the subplot error term.

Cultivars resistance to BF1 strain. The second experimental setup was undertaken in a glasshouse at the Institute of Research and Development in Montpellier, France. The temperature ranged from 28 to $32^{\circ} \mathrm{C}$, and there were $12 \mathrm{hr}$ of light per $24 \mathrm{hr}$, and 80 to $90 \%$ relative humidity. Accession BM24 was evaluated along with Asian rice accession HB18B from Burkina Faso, seven Asian rice accessions from the rice collection of the Mini Gene Bank (MiniGB) of the "Centre de coopération Internationale en Recherche Agronomique pour le Développement" (CIRAD, Montpellier, France), and three check cultivars (IR64, CG14 and Azucena). The seven accessions of the MiniGB were three Asian rice var. indica (ASD1, CO18 and PTB9), three Asian rice var. japonica (Pagaiyahan, Jumali and Malapkit-Pirurutong) and one accession from Glaszmann's group V (ARC13829).

Twenty-eight plants of each accession were sown in a tray of 28 holes, with 14 plants in one tray; and the remaining 14 plants in another tray. Then, each tray included two different accessions allocated randomly. The seed trays were replicated twice in the two treatments (the control non-infected and the infected) and arranged in a completely randomised design. The last fully expanded leaf for each plant was mechanically inoculated, 2 weeks after sowing with BF1. Such an aggressive isolate was selected to maximise differences in host response to infection among resistant and susceptible cultivars. The 1-9 scale for disease scoring was used to record leaf number at 4, 7, 11, 14 and $21 \mathrm{dpi}$. Plant height was measured at 7,14 , and $21 \mathrm{dpi}$ to compare height differences between accessions at early stages. The area under symptoms progression curve (AUSPC) was calculated as Boisnard et al. (2007) to measure disease progress as:

AUSPC $=\Sigma\left[\left(S_{i}+S_{i+1}-2\right)\left(T_{i+1}-T_{i}\right)\right] / 2 \ldots$

Where:

$S_{\mathrm{i}}$ and $S_{(\mathrm{i}+1)}$ were the symptom scores at time $T_{\mathrm{i}}$ and $T_{(\mathrm{i}+1)}$, respectively, and $n$ was the total number of observations.

The ANOVA for plant height, leaf number and disease score considering the accession $x$ treatment interaction was computed using the GeneStat software Version 12 (Payne et al., 2009). A $t$-test was used to compare the mean performance of inoculated accessions and their respective control.

At $14 \mathrm{dpi}$, the last fully expanded leaf of each individual plant was collected to evaluate virus content through the enzyme-linked immunosorbent assay (ELISA). ELISA tests were performed as described in Ndjiondjop et al. (1999).

A piece of $20 \mathrm{~mm}$ of the last leaves was cut at 14 dpi for DNA extraction with the aim of comparing the allelic profile of locus RM101 in chromosome 12 . The DNA was extracted as described by Edwards et al. (1991). The PCR amplification was performed in a 96-well thermocycler (Tgradient, Biometra) on $5 \mathrm{ng}$ of DNA in a $15 \mu \mathrm{l}$ final volume of buffer $(10 \mathrm{mM}$ Tris- $\mathrm{HCl} \mathrm{pH} 8$, $100 \mathrm{mM} \mathrm{KCl}, 0.05 \% \mathrm{w} / \mathrm{v}$ gelatin, and $2.0 \mathrm{mM}$ $\mathrm{MgCl}_{2}$ ) containing $0.1 \mu \mathrm{M}$ of reverse primer $\mathrm{RM} 101,0.08 \mu \mathrm{M}$ of forward primer RM101, 
$200 \mu \mathrm{M}$ of dNTP, and $0.1 \mathrm{U}$ of Taq DNA polymerase. The PCR protocol used included the initial denaturation at $94^{\circ} \mathrm{C}$ for $4 \mathrm{~min}, 35$ cycles of $94^{\circ} \mathrm{C}$ for $60 \mathrm{~s}$, hybridisation temperature $55^{\circ} \mathrm{C}$ for $60 \mathrm{~s}$ and $72^{\circ} \mathrm{C}$ for $60 \mathrm{~s}$; and a final elongation step at $72^{\circ} \mathrm{C}$ for $8 \mathrm{~min}$. The products of amplification were revealed on $2 \%$ agarose gel.

\section{RESULTS}

Interactions with $\mathrm{Ng117b}, \mathrm{Ng122}$ and $\mathrm{Ng144}$ isolates. There were significant accession $x$ treatment $(\mathrm{P}<0.001)$, time $\times$ accession $(\mathrm{P}=$ $0.049)$, and time $\times$ treatment $(\mathrm{P}=0.013)$ interaction effects for host plant resistance to RMYV.

$\mathrm{Ng} 122$ isolate triggered more symptom expression in varieties Azucena, BM24, IR64 and Tog5681 than isolates $\mathrm{Ng} 117 \mathrm{~b}$ and $\mathrm{Ng} 144$ (Fig. 1). Ng144 infected more Gigante than both $\mathrm{Ng} 117 \mathrm{~b}$ and $\mathrm{Ng} 122$. IR64 showed susceptibility to all isolates with a score above 5 , with leaf mottling and yellowing; while Tog5681 showed inconspicuous symptoms with scores below 2 (Fig. 1).

There was a highly significant accession $x$ treatment interaction $(P=0.003)$ for plant height (Table 1). Plant height differences between the infected accessions of BM24, Gigante, and Tog5681, vis-à-vis their respective controls, were not significantly different $(P>0.05)$ across the three isolates. Both $\mathrm{Ng} 144$ and $\mathrm{Ng} 122$ induced a significant height reduction in Azucena $(\mathrm{P}<0.05)$ and IR64 $(\mathrm{P}<0.05$, respectively.

$\mathrm{Ng} 122$ caused pronounced symptoms on IR64 (disease score $>7$ ), but induced limited damage on Azucena (disease score $=3$ ). The three isolates induced up to $10 \%$ plant height reduction in the local cultivar BM24 (Table 1). $\mathrm{Ng} 144$ and $\mathrm{Ng} 122$ overcame the resistance of Gigante, causing a $14 \%$ plant height reduction (Table 1). In contrast, Tog5681 did not show a significant plant height reduction $(<3 \%)$ for the three isolates.

The accessions displayed different resistance and susceptibility patterns as visualised by symptoms and measured by plant height (Table 1). Tog5681 was resistant to all isolates. Gigante showed no symptom to the isolate $\mathrm{Ng} 117 \mathrm{~b}$ until $42 \mathrm{dpi}$, where sparse dots appeared on its leaves. $\mathrm{Ng} 122$ overcame the resistance of Gigante, with mild leaf symptoms at $42 \mathrm{dpi}$; and had a $14 \%$ plant height reduction at $49 \mathrm{dpi}$; while symptom

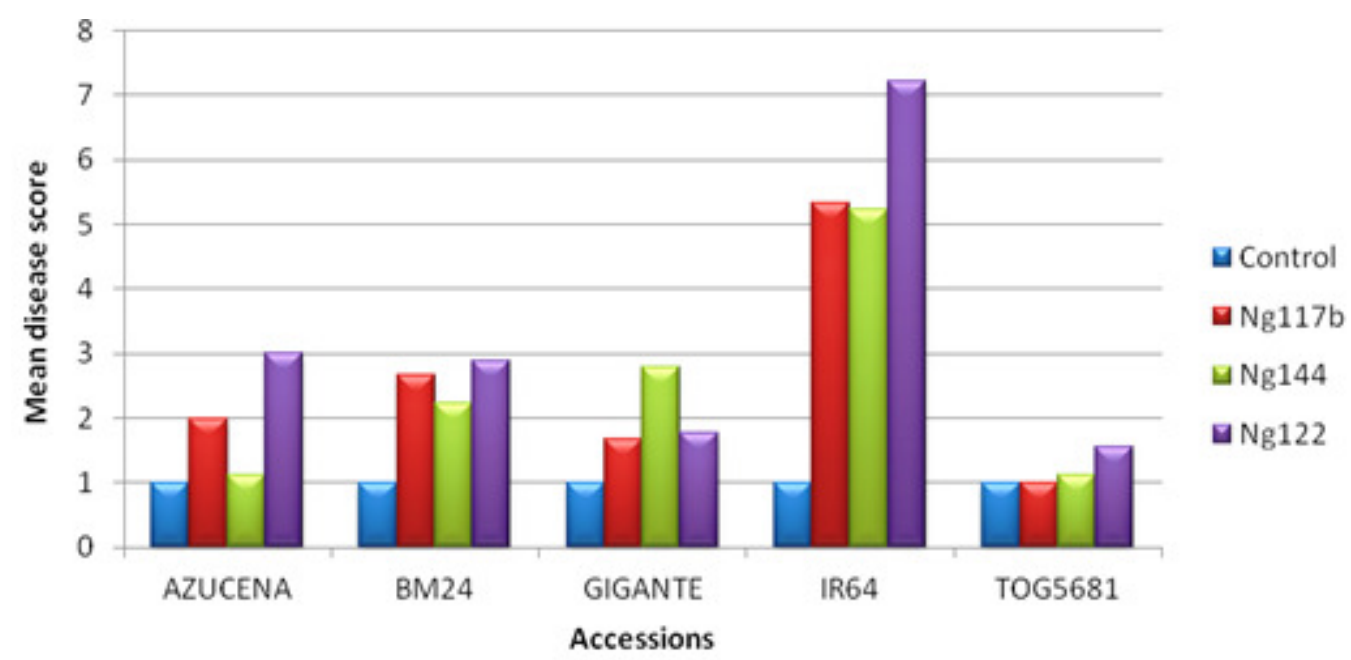

Figure 1. Distribution of the resistance statute of five accessions to the infection of $\mathrm{Ng} 117 \mathrm{~b}, \mathrm{Ng} 144, \operatorname{and} \mathrm{Ng} 122$ isolates of Rice yellow mottle virus vis-à-vis non-infected control at 14 days post infection. 
TABLE 1. Rice plant height at 49 days post inoculation after inoculating with Rice yellow mottle virus isolates in screenhouse

\begin{tabular}{lrrrl}
\hline Accessions & \multicolumn{4}{c}{ Plant height $\left(\mathrm{mm}^{*}\right)$} \\
\cline { 2 - 4 } & Control & Ng117b & Ng144 & Ng122 \\
\hline Azucena & $990 \mathrm{a}$ & $783 \mathrm{a}$ & $700 \mathrm{~b}$ & $880 \mathrm{a}$ \\
BM24 & $873 \mathrm{a}$ & $810 \mathrm{a}$ & $887 \mathrm{a}$ & $867 \mathrm{a}$ \\
Gigante (resistant check) & $1107 \mathrm{a}$ & $1100 \mathrm{a}$ & $973 \mathrm{a}$ & $973 \mathrm{a}$ \\
IR64 (susceptible check) & $813 \mathrm{a}$ & $697 \mathrm{a}$ & $700 \mathrm{a}$ & $217 \mathrm{~b}$ \\
TOG5681 (resistant check) & $1010 \mathrm{a}$ & $1003 \mathrm{a}$ & $1010 \mathrm{a}$ & $983 \mathrm{a}$ \\
\hline
\end{tabular}

*Average of three replications. Mean separation in a row by Least Significance Difference (LSD) test at 5\% level. Means followed by the same letter are not significantly different at the 5\% level

expression was noted in this cultivar at $28 \mathrm{dpi}$ and $14 \%$ plant height reduction at 49 dpi when infected by Ng144 (Table 1).

Azucena had green leaves, with sparse dots and a relatively high plant height reduction (21and 11\%) when infected with $\mathrm{Ng} 117 \mathrm{~b}$ and $\mathrm{Ng} 122$, respectively. In contrast, mild symptoms on leaves and a statistically significant plant height reduction was observed for Azucena after being inoculated with $\mathrm{Ng} 144$ (Table 1). BM24 showed a 10\% plant height reduction and mild symptoms (green leaves with sparse dots) throughout the screening period when inoculated with all isolates. Azucena and BM24 had therefore different resistance level regarding the three isolates.

Resistance to BF1 strain. Leaf symptoms varied among accessions and across time (Table 2). Symptoms were not noticed at 4 dpi. A significant accession $\times$ disease score interaction was noted at 7 and $14 \mathrm{dpi}$ ( $\mathrm{P}=0.0003$ and $\mathrm{P}=0.018$, respectively). At 7 dpi, most accessions (except Azucena and BM24) exhibited leaf symptoms. The leaves of BM24 were still symptomless at $11 \mathrm{dpi}$ (Table 3).

Leaf symptoms were noticeable in all accessions at $14 \mathrm{dpi}$. Symptoms were delayed in Azucena and BM24, until 11 and 14 dpi, respectively. None of the accessions was symptomless to BF1 at $21 \mathrm{dpi}$. There was a highly significant accessions $\times$ treatment interaction for plant height at 7 and $14 \mathrm{dpi}$ $(\mathrm{P}<0.0001)$. Plant height was significantly different between the infected accessions and their respective non-inoculated controls at 7 and 14 dpi (Table 3). Although, Azucena and BM24 did not show leaf symptoms at 7 dpi, $\mathrm{BF} 1$ induced a significant plant height reduction in both (65 and $45 \mathrm{~mm}$, respectively). This plant height reduction increased at $14 \mathrm{dpi}$ : $107 \mathrm{~mm}$ for Azucena and $67 \mathrm{~mm}$ for BM24, respectively. A 10\%, plant height reduction was observed in Malagkit and BM24 at 7 and 14 dpi (Table 3).

Malagkit and CG14 showed susceptibility as the susceptible check IR64, while Azucena and BM24 showed partial resistance. Azucena and BM24 had delayed symptom expression for at least 11 days, but Azucena showed more symptoms than BM24 at 11 dpi however, the two accessions had score 3 at 21 dpi.

The accessions $\times$ treatment interaction for leaf number was non-significant. Infected and control plant differed in their leaf number that increased significantly with time (Table 4). IR64 was the most susceptible cultivar as measured by the AUSPC, while BM24 and Azucena had the lowest AUSPC (Fig. 2).

Symptom expression evolved rapidly in the susceptible cultivars such as IR64, while it was delayed in the partial resistant cultivars Azucena and BM24. ELISA revealed a highly significant $(\mathrm{P}<0.001)$ viral content among accessions at $14 \mathrm{dpi}$. Viral content was 
TABLE 2. Host plant resistance of 12 rice accessions inoculated with Rice yellow mottle virus isolate BF1 at 7 , 11 and 14 days post infection (dpi)

\begin{tabular}{|c|c|c|c|}
\hline \multirow[t]{2}{*}{ Accession } & \multicolumn{3}{|c|}{ Difference $^{\text {a }}$ (score control - score inoculated) } \\
\hline & 7 dpi & $11 \mathrm{dpi}$ & 14 dpi \\
\hline ARC & $1.63^{* * *}$ & $4.00^{* * *}$ & $4.00^{* * *}$ \\
\hline ASD1 & $1.56^{* * *}$ & $2.57^{* * *}$ & $4.00^{* * *}$ \\
\hline Azucena & $0.14^{\mathrm{ns}}$ & $0.78^{*}$ & $1.57^{* * *}$ \\
\hline BM24 & $0.00 \mathrm{~ns}$ & $0.07 \mathrm{~ns}$ & $1.00^{* *}$ \\
\hline CG14 & $2.84^{* * *}$ & $3.57^{* * *}$ & $3.85^{* * *}$ \\
\hline $\mathrm{CO} 18$ & $2.20^{* * *}$ & $4.00^{* * *}$ & $4.00^{* * *}$ \\
\hline HB18B & $0.92^{* *}$ & $3.71^{* * *}$ & $4.00^{* * *}$ \\
\hline IR64 & $2.70^{* * * *}$ & $4.00^{* * * *}$ & $5.35^{\text {*** }}$ \\
\hline Jumali & $1.77^{* * *}$ & $3.42^{* * *}$ & $4.00^{* * *}$ \\
\hline Malagkit & $0.99^{* *}$ & $3.42^{* * *}$ & $3.00^{* * *}$ \\
\hline PTB & $1.99^{* * *}$ & $3.35^{* * * *}$ & $3.50^{\text {*** }}$ \\
\hline Pagaiyan & $2.41^{* * * *}$ & $3.42^{* * *}$ & $3.71^{* * *}$ \\
\hline
\end{tabular}

aMean of 28 replications. $* * *=$ significant at $0.1 \%$ level, ** significant at $1 \%$ level, * significant at $5 \%$ level, ns $=$ not significant

TABLE 3. Effect of isolate BF1 on plant height of the 12 accessions at 7 days post inoculation (dpi) and at 14 dpi

\begin{tabular}{|c|c|c|c|c|}
\hline \multirow[t]{2}{*}{ Accession } & \multicolumn{2}{|c|}{ Plant height comparison at $7 \mathrm{dpi}^{\mathrm{a}}$} & \multicolumn{2}{|c|}{ Plant height comparison at $14 \mathrm{dpi}^{\mathrm{a}}$} \\
\hline & $\begin{array}{c}\text { Reduction } \\
(\%)\end{array}$ & $\begin{array}{l}\text { Difference } \\
\quad(\mathrm{mm})\end{array}$ & $\begin{array}{l}\text { Reduction } \\
(\%)\end{array}$ & $\begin{array}{l}\text { Difference } \\
(\mathrm{mm})\end{array}$ \\
\hline ARC & 7.7 & $36^{* *}$ & 14.7 & $86^{* * *}$ \\
\hline ASD1 & 19.8 & $111^{* * *}$ & 25.4 & $181^{* * *}$ \\
\hline Azucena & 12.7 & $65^{* * *}$ & 15.5 & $107^{* * * *}$ \\
\hline BM24 & 9.5 & $45^{* * *}$ & 10.5 & $67^{* * *}$ \\
\hline CG14 & 15.9 & $81^{* * *}$ & 23.5 & $171^{* * *}$ \\
\hline $\mathrm{CO} 18$ & 16.2 & $79^{* * * *}$ & 33.6 & $216^{* * * *}$ \\
\hline HB18B & 10.7 & $61^{* * * *}$ & 22.1 & $158^{* * * *}$ \\
\hline IR64 & 14.5 & $64^{* * *}$ & 32.5 & $189^{* * *}$ \\
\hline Jumali & 26.3 & $160^{* * *}$ & 39.2 & $316^{* * *}$ \\
\hline Malagkit & 10.1 & $46^{* * * *}$ & 9.6 & $61^{* * *}$ \\
\hline PTB & 14.7 & $69^{* * *}$ & 20.4 & $125^{* * *}$ \\
\hline Pagaiyan & 20.6 & $109^{* * *}$ & 21.5 & $146^{* * *}$ \\
\hline
\end{tabular}

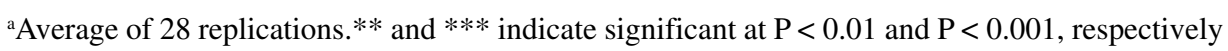


TABLE 4. ANOVA of data on leaf number in a CRD with 28 replications taken at 4; 7; 11; 14 and 21 dpi

\begin{tabular}{lrrrrr}
\hline & \multicolumn{5}{c}{ ProbF } \\
\cline { 2 - 6 } & Leave 4 & Leave 7 & Leave 11 & Leave 14 & Leave 21 \\
\hline Accession0,003 & 0,0005 & 0,0013 & 0,008 & 0,02 & \\
Treatment & 0,011 & 0,003 & 0,001 & 0,00002 & $1,47 \mathrm{E}-08$ \\
Treatment*accession & 0,9998 & 0,9999 & 0,9994 & 0,9491 & 0,9079 \\
\hline
\end{tabular}

CRD: Complete Randomised Design

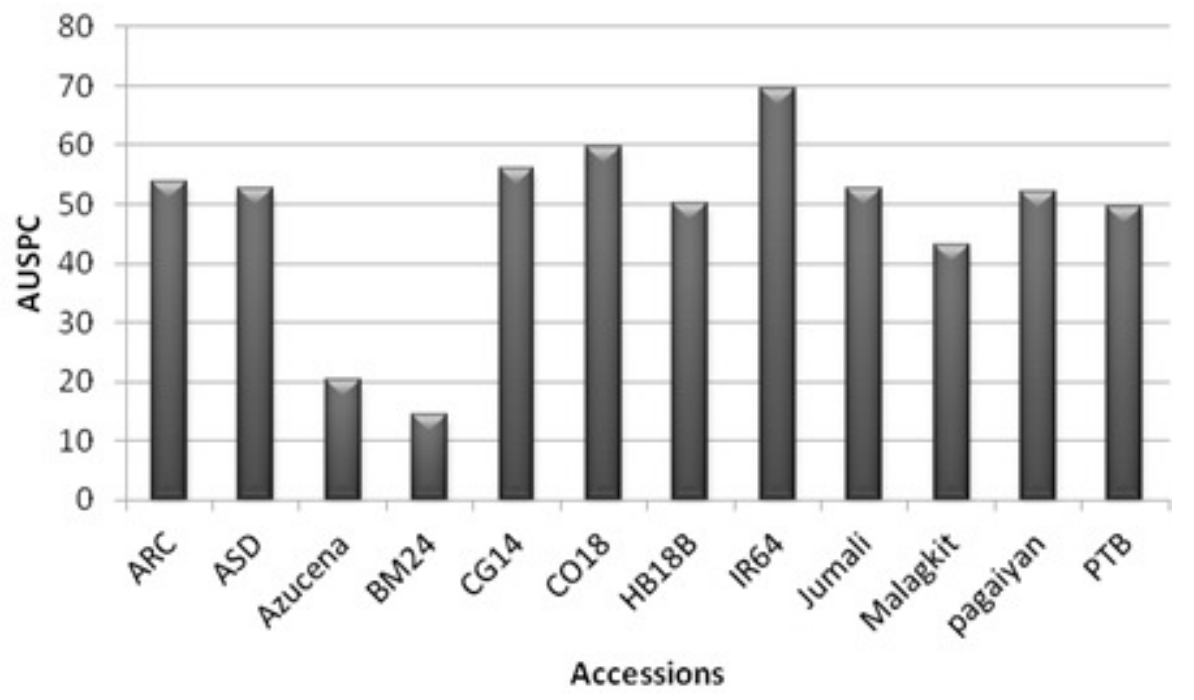

Figure 2. Distribution of resistance, estimated by Area under symptom progress curve (AUSPC) values, in 12 rice accessions inoculated with RYMV BF1 isolate.

significantly lower in BM24 than in Azucena (Fig. 3). The assessment of the RM101 locus profile distinguished three groups with different allele sizes (Fig. 4).

The first group (260 bp allele) included IR64, CG14, HB18B, Jumali, MalapkitPirurutong and Pagaiyahan, while ARC, ASD1, CO18 and PTB9 were in the second group (300 pb allele), and third group (320 bp allele) consisted of Azucena and BM24.

\section{DISCUSSION}

Interactions with Ng117b, Ng122 and Ng144 isolates. The screening with different RYMV isolates $(\mathrm{Ng} 117 \mathrm{~b}, \mathrm{Ng} 122$, and $\mathrm{Ng} 144)$ confirmed the host plant resistance of local cultivar BM24 (Table 1). It also demonstrated that this cultivar has partial host plant resistance, which seems to be similar to the one found in the Asian rice var. japonica cv. Azucena (Albar et al., 1998). BM24 had 10\% plant height reduction and mild symptom expressions against $\mathrm{Ng} 117 \mathrm{~b}, \mathrm{Ng} 122$, and Ng144 (Table 1). Partially resistant plants, even with mild symptoms, may show stunted growth after RYMV infection. The resistance mechanism delaying symptoms or blocking RYMV spreading appears to affect plant growth. Tog5681 was resistant to RYMV isolates $\mathrm{Ng} 117 \mathrm{~b}, \mathrm{Ng} 122$, and $\mathrm{Ng} 144$ with inconspicuous height reduction. Differences 


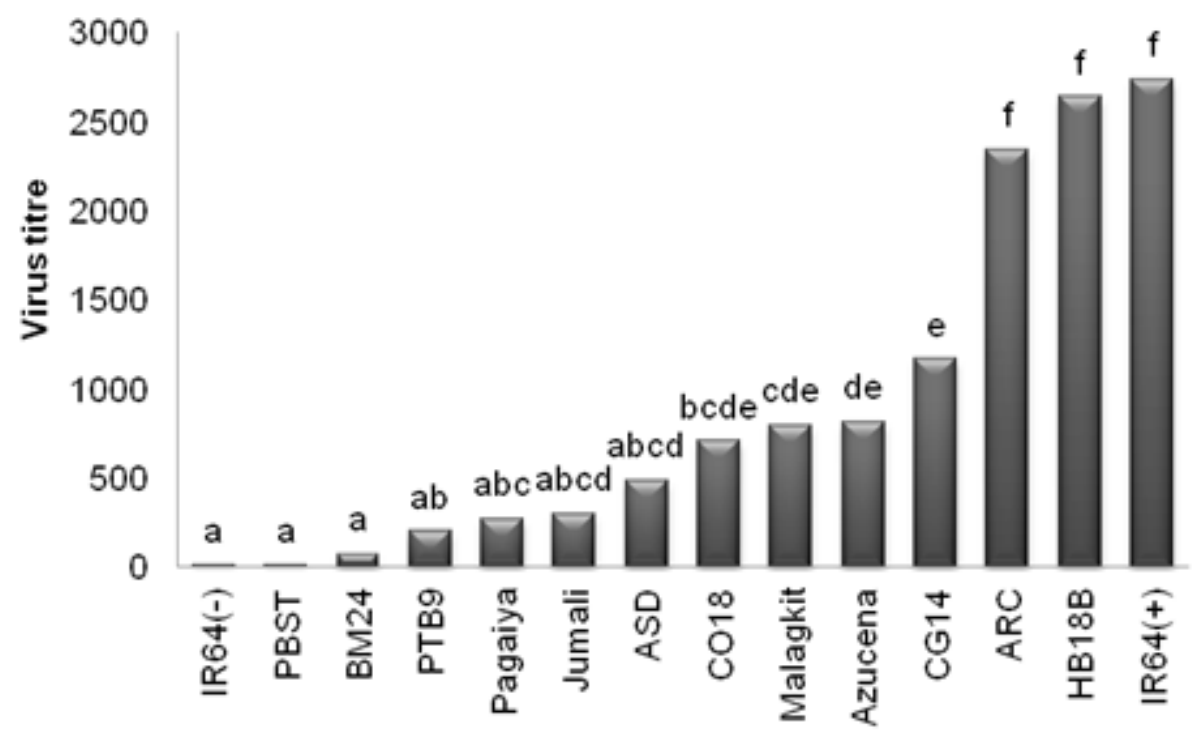

Figure 3. Distribution of the virus titer of 12 rice accessions at 14 days post inoculation (dpi). Means titer followed by a same letter are not significantly different.

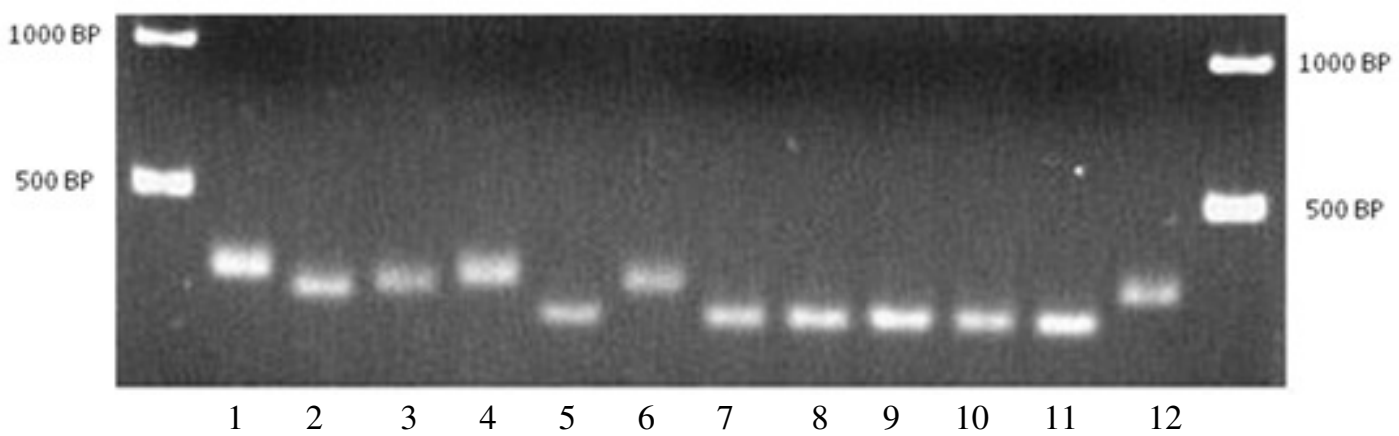

Figure 4. Allelic comparison at locus RM101 for Azucena (1), ARC (2), ASD1 (3), BM24 (4), CG14 (5), CO18 (6), HB18B (7), IR64 (8), Jumali (9), Malapkit (10), Pagaiyan (11) and PTB9 (12).

in plant height between inoculated and noninoculated control plants, along with disease scoring provide a reliable assessment of host plant resistant to RMYV. Azucena and BM24 had distinct host plant resistance to the isolates included in our research. This finding could be due to different resistance genes or QTLs in these accessions, which limit RYMV damage to the host plant (Ioannidou et al., 2003; Ventelon-Debout et al., 2008). The virulence of novel isolates of RYMV against major genes for RYMV resistance was established by Fargette et al. (2002a). Several authors have established that virulent isolates overcome the major gene RYMVI (Sorho et al., 2005; Hébrard et al., 2006; Traoré et al., 2006; Pinel-Galzi et al., 2007; Poulicard et al., 2009; Traoré et al., 2010). This finding was not surprising because of high mutation rates in RYMV, which is a virus that evolves rapidly (Fargette et al., 2008a).

Multiple RYMV strains are widespread in Africa (Pinel-Galzi et al., 2007; Fargette et al., 2008b; Salaudeen et al., 2010). The West 
African strains were confirmed to mostly include isolates with threonine ("Tpathotype"); while a few isolates (called "Epathotype") had glutamic acid. Ng122 is virulent to the host plant resistance of Tog5681 at $42 \mathrm{dpi}$. This isolate could have a threonine at codon 49. According to Traoré et al. (2010), only RYMV isolates with a threonine at codon 49 of the viral protein genome-linked (VPg) can break the resistance allele Rymv1-3 (found in Tog5681). Ng144 broke Gigante's host plant resistance to RYMV (Fig. 1). This host plant resistance was also ineffective against $\mathrm{Ng} 122$. Ng122 could belong to a subset of isolates with virulence matching the recessive resistance alleles Rymv1-2 and Rymv1-3 found in Gigante and Tog5681, respectively. The Rymv1-2 allele is known to be ineffective against isolates with "Epathotypes" (Pinel-Galzi et al., 2007; Poulicard et al., 2009). Very few RYMV isolates from West African S2/S3 strains overcame host plant resistance of both Gigante and Bekarosaka (Pinel-Galzi et al., 2007; Poulicard et al., 2009). "T-pathotypes" seldom overcome host plant resistance provided by Rymv1-2. On the contrary, they easily overcome host plant resistance from Rymv1-3 present in Tog5681 (Pinel-Galzi et al., 2007; Poulicard et al., 2009; Traoré et al., 2010). Moreover, Traoré et al. (2010) established that some T strains (S2/S3) and some T isolates from Niger were able to overcome host plant resistance of both Gigante and Tog5681. Partial resistance, along with high resistance due to major gene(s), could be the best strategy to control RYMV.

Resistance to BF1 strain. Screening for partial resistance with BF1 over 21 dpi was able to characterise the 12 rice accessions (Table 2). BF1 induced very different symptoms at early stages of infection. Symptoms were expressed in all accessions at 21 dpi. Likewise, ELISA at 14 dpi was able to discriminate susceptible and partially resistant accessions. Two weeks after inoculation appears to be the optimal period to assess virus titer when assessing for partial resistance to RYMV (Ghesquière et al., 1997). Cultivars combining partial resistance with tolerance may be less affected after RYMV infection, but they will remain as reservoirs of this virus (Ioannidou et al., 2000).

Screening with BF1 further corroborated the previous finding, and suggests that BM24 and Azucena could have same genotype at the RM101 locus, which is associated with QTL12 that provides partial resistance to RYMV (Ioannidou et al., 2000; Boisnard et al., 2007).

BM24 could be used for QTL12 fine mapping, which has been difficult in offspring derived from IR64 and Azucena (Boisnard et al., 2007). QTL12 appears to be close to the indica-japonica zone of differentiation and recombination between Azucena and IR64 seldom occurs (Ghesquière et al., 1997; Boisnard et al., 2007). Besides its partial resistance to RYMV, Azucena shows tolerance to this virus at later stages (Ioannidou et al., $2000 \& 2003)$. The DNA profiling at the RM101 locus was, however, the same for both Azucena and BM24. The partial resistance in Azucena has been shown to be due to both QTL12 and QTL7 (Pressoir et al., 1998; Ahmadi et al., 2001; Ioannidou et al., 2003); while the tolerance was associated with the expression of QTL1 (Ioannidou et al., 2000). QTL mapping research should therefore, be undertaken on BM24 cultivar to elucidate if it shares the same QTLs of Azucena.

Partial resistance alone cannot block virus infection and further multiplication (Ioannidou et al., 2003). Other resistance genes to RMYV are, therefore, needed to provide better host plant resistance to this virus. Combining monogenic and multi-genic host plant resistance may lead to durable resistance in the cultigens (Van Der Plank, 1966; Rubiales and Niks, 2000).

\section{CONCLUSION}

Screening with the three different RYMV isolates $(\mathrm{Ng} 117 \mathrm{~b}, \mathrm{Ng} 122$, and $\mathrm{Ng} 144)$ has 
confirmed the high level of host plant resistance of the $O$. glaberrima check variety TOG5681; while the resistance breaking events occurred in the $O$. sativa check variety Gigante when infected by the isolate $\mathrm{Ng} 144$. The local cultivar BM24 has moderate resistance across the three isolates. Also, this cultivar shows partial host plant resistance, which seems to be similar to the one noted in Asian rice var. japonica cv. Azucena. Screening with BF1 further corroborates the previous finding, and suggested that BM24 and Azucena could have same genotype at the RM101 locus, which is associated with QTL12 that provides partial resistance to RYMV. QTL12 appears to be close to the indica-japonica zone of differentiation and recombination between Azucena and IR64 seldom occurs. BM24 could be used for QTL12 fine mapping, which has been difficult in offspring derived from IR64 and Azucena.

\section{ACKNOWLEDGMENT}

This work was partially funded through a GCP project (G4009.02.01) and financially supported by AfricaRice and USAID through a Grant to the project "Marker-Assisted Selection for the improvement of rice varieties resistance to RYMV for West Africa".

\section{REFERENCES}

Abubakar, Z., Ali, F., Pinel, A., Traoré, O., N'Guessan, P., Notteghem, J-L., Kimmins, F., Konaté, G. and Fargette, D. 2003. Phylogeography of Rice yellow mottle virus in Africa. Journal of General Virology 84:733-743.

Ahmadi, N., Albar, L., Pressoir, G., Pinel, A., Fargette, D. and Ghesquière, A. 2001. Genetic basis and mapping of the resistance to Rice yellow mottle virus. III. Analysis of QTL efficiency in introgressed progenies confirmed the hypothesis of complementary epistasis between two resistance QTLs. Theoretical and Applied Genetics 103:1084-1092.
Albar, L., Bangratz-Reyser, M., Hébrard, E., Ndjiondjop, M.-N., Jones, M. and Ghesquière, A. 2006. Mutations in the eIF(iso) $4 \mathrm{G}$ translation initiation factor confer high resistance of rice to Rice yellow mottle virus. Plant Journal 47:417426.

Albar, L., Lorieux, M., Ahmadi, N., Rimbault, I., Pinel, A., Sy, A.A., Fargette, D. and Ghesquiere, A. 1998. Genetic basis and mapping of the resistance to Rice yellow mottle virus. I. QTLs identification and relationship between resistance and plant morphology. Theoretical and Applied Genetics 97:1145-1154.

Boisnard, A., Albar, L., Thiéméle, D., Rondeau, M. and Ghesquière, A. 2007. Evaluation of genes from eIF4E and eIF4G multigenic families as potential candidates for partial resistance QTLs to Rice yellow mottle virus in rice. Theoretical and Applied Genetics 116:53-62.

Edwards, K., Johnstone, C. and Thompson, C. 1991. A simple and rapid method for the preparation of plant genomic DNA for PCR analysis. Nucleic Acids Research 19:1389.

Fargette, D., Pinel, A., Traoré, O., Ghesquière, A. and Konaté, G. 2002a. Emergence of resistance-breaking isolates of Rice yellow mottle virus during serial inoculations. European Journal of Plant Pathology 108:585-591.

Fargette, D., Pinel, A., Halimi, H., Brugidou, C., Fauquet, C. and Regenmortel, M.V. 2002b. Comparison of molecular and immunological typing of isolates of Rice yellow mottle virus. Archives of Virology 147:583-596.

Fargette, D., Pinel-Galzi, A., Sérémé, D., Lacombe, S., Hébrard, E., Traoré, O. and Konaté, G. 2008a. Diversification of Rice yellow mottle virus and related viruses spans the history of agriculture from the neolithic to the present. PLoS Pathogens 4:1-8. 
Fargette, D., Pinel, A., Abubakar, Z., Traore, O., Brugidou, C., Sorho, F., Hebrard, E., Choisy, M., Sere, Y., Fauquet, C. and Konate, G. 2004. Inferring the evolutionary history of Rice yellow mottle virus from genomic, phylogenetic, and phylogeographic studies. Journal of Virology 78:3252-3261.

Fargette, D., Pinel, A., Rakotomalala, M., Sangu, E., Traoré, O., Sérémé, D., Sorho, F., Issaka, S., Hébrard, E., Séré, Y., Kanyeka, Z. and Konaté, G. 2008b. Rice yellow mottle virus, an RNA plant virus, evolves as rapidly as most RNA animal viruses. Journal of Virology 82:3584-3589.

Fomba, S.N. 1988. Screening for seedling resistance to Rice yellow mottle virus in some rice cultivars in Sierra Leone. Plant Disease 72:641-642.

Ghesquière, A., Albar, L., Lorieux, M., Ahmadi, N., Fargette, D., Huang, N., McCouch, S.R. and Notteghem, J.L. 1997. A major quantitative trait locus for Rice yellow mottle virus resistance maps to a cluster of blast resistance genes on chromosome 12. Phytopathology 87:12431249.

Hébrard, E., Pinel-Galzi, A., Bersoult, A., Siré, C. and Fargette, D. 2006. Emergence of a resistance-breaking isolate of Rice yellow mottle virus during serial inoculations is due to a single substitution in the genomelinked viral protein VPg. Journal of General Virology 87:1369-1373.

Ioannidou, D., Lett, M., Pinel, A., Assigbetse, K., Brugidou, C., Ghesquière, A., Nicole, M. and Fargette, D. 2000. Responses of Oryza sativa japonica sub-species to infection with Rice yellow mottle virus. Physiological and Molecular Plant Pathology 57:177-188.

Ioannidou, D., Pinel, A., Brugidou, C., Albar, L., Ahmadi, N., Ghesquiere, A., Nicole, M. and Fargette, D. 2003. Characterisation of the effects of a major QTL of the partial resistance to Rice yellow mottle virus using a near-isogenic-line approach.
Physiological and Molecular Plant Pathology 63:213-221.

International Rice Research Institute (IRRI). 2002. Standard evaluation system (SES) for rice. International Rice Research Institute, Los Baños, Philippines.

Kam, H., Laing, M.D. Séré, Y., Thiémélé, D., Ghesquière, A., Ahmadi, N. and Ndjiondjop, M.-N. 2013. Evaluation of a collection of rice landraces from burkina faso for resistance or tolerance to rice yellow mottle virus. Journal of Plant Pathology 95 (3): 485-492.

Kouassi, N.K., N'Guessan, P., Albar, L., Fauquet, C.M. and Brugidou, C. 2005. Distribution and characterization of Rice yellow mottle virus: A threat to African farmers. Plant Disease 89:124-133.

Ndjiondjop, M.N., Albar, L., Fargette, D., Fauquet, C. and Ghesquiere, A. 1999. The genetic basis of high resistance to Rice yellow mottle virus (RYMV) in cultivars of two cultivated rice species. Plant Disease 83:931-935.

Ndjiondjop, M.N., Brugidou, C., Zang, S., Fargette, D., Ghesquiere, A. and Fauquet, C. 2001. High resistance to Rice yellow mottle virus in two cultivated rice cultivars is correlated to failure of cell to cell movement. Physiological and Molecular Plant Pathology 59:309-316.

Payne, R. W., Murray, D. A., Harding, S. A., Baird, D.B. and Soutar, D. M. 2009. GeneStat for Windows (12 $2^{\text {th }}$ Edition) Introduction. VSN International, Hemel Hempstead.

Pinel-Galzi, A., Rakotomalala, M., Sangu, E., Sorho, F., Kanyeka, Z., Traoré, O., Sérémé, D., Poulicard, N., Rabenantoandro, Y., Séré, Y., Konaté, G., Ghesquiere, A., Hébrard, E. and Fargette, D. 2007. Theme and variations in the evolutionary pathways to virulence of an RNA plant virus species. PLoS Pathogens 3:1761-1770.

Poulicard, N., Pinel-Galzi, A., Hebrard, E. and Fargette, D. 2009. Why Rice yellow mottle virus, a rapidly evolving RNA plant virus, 
is not efficient at breaking Rymv1-2 resistance. Molecular Plant Pathology 11:145-154.

Pressoir, G., Albar, L., Ahmadi, N., Rimbault, I., Lorieux, M., Fargette, D. and Ghesquiere, A. 1998. Genetic basis and mapping of the resistance to Rice yellow mottle virus. II. Evidence of a complementary epistasis between two QTLs. Theoretical and Applied Genetics 97:1155-1161.

Rakotomalala, M., Pinel-Galzi, A., Albar, L., Ghesquière, A., Rabenantoandro, Y., Ramavovololona, P. and Fargette, D. 2008. Resistance to Rice yellow mottle virus in rice germplasm in Madagascar. European Journal of Plant Pathology 122:277-286.

Rubiales, D. and Niks, R.E. 2000. Combination of mechanisms of resistance to rust fungi as a strategy to increase durability. pp. 333339. In: Options méditerranéennes, Serie A: Séminaires Méditerrannéennes, Numéro 40. Durum wheat improvement in the Mediterranean region: New challenges. Royo, C., Nachit, M.M.N. and Di Fonzo, J.L. (Eds.). Proceeding of the seminar jointly organized by CIHEAM, Centre UdlIRTA, CIMMYT and ICARDA. Zaragoza (Spain): 12-14 April 2000.

Salaudeen, M.T., Banwo, O.O., Kashina, B.D. and Alegbejo, M.D. 2010. Current status of research on rice yellow mottle Sobemovirus. Archives of Phytopathology and Plant Protection 43:562-572.

Sorho, F., Pinel, A., Traoré, O., Bersoult, A., Ghesquiere, A., Hébrard, E., Konaté, G., Séré, Y. and Fargette, D. 2005. Durability of natural and transgenic resistances in rice to Rice yellow mottle virus. European Journal of Plant Pathology 112:349-359.

Sow, M., Ndjiondjop, M.-N., Dieng, I., Kam, H., Kolade, O. and Laing M. 2015. Interactions Between Rice yellow mottle virus (RYMV) Isolates and Rice Germplasm from Niger. Tropical Plant Pathology. DOI 10.1007/s40858-0150006-z.

Thiémélé, D., Boisnard, A., Ndjiondjop, M.N., Chéron, S., Séré, Y., Aké, S., Ghesquière, A. and Albar, L. 2010. Identification of a second major resistance gene to Rice yellow mottle virus, RYMV2, in the African cultivated rice species, O. glaberrima. Theoretical and Applied Genetics 121:169179.

Traoré, O., Pinel, A., Hébrard, E., Gumedzoe, M.Y.D., Fargette, D., Traoré, A.S. and Konaté, G. 2006. Occurrence of resistance-breaking isolates of Rice yellow mottle virus in West and Central Africa. Plant Disease 90:259-263.

Traoré, O., Pinel-Galzi, A., Issaka, S., Poulicard, N., Aribi, J., Aké, S., Ghesquière, A., Séré, Y., Konaté, G., Hébrard, E. and Fargette, D. 2010. The adaptation of Rice yellow mottle virus to the eiF(iso)4G-mediated rice resistance. Virology 408:103-108.

Van Der Plank, J. 1966. Horizontal (polygenic) and vertical (oligogenic) resistance against blight. American Potato Journal 43:43-52. Ventelon-Debout, M., Tranchant-Dubreuil, C., Nguyen, T.-T.-H., Bangratz, M., Siré, C., Delseny, M. and Brugidou, C. 2008. Rice yellow mottle virus stress responsive genes from susceptible and tolerant rice genotypes. BMC Plant Biology 8:1-12. 